\title{
Humanitært arbeid må telle
}

\author{
Humanitært arbeid er anerkjent i helsevesenet, men når det gjelder godkjenning av tjenesten, kan pipen \\ lett få en annen lyd. Er det mulig å standardisere godkjenning av medisinsk arbeid i felten som en del \\ av spesialiseringen?
}

Mange operasjoner og oppdrag for humanitære organisasjoner sammenfaller med katastrofer. Som lege i spesialisering er det ofte vanskelig å få permisjon på kort varsel til slike oppdrag. Naturlig nok får man som oftest ikke forvarsel om når en katastrofe vil inntreffe, og arbeidsgiver ønsker å planlegge drift og turnus langt frem $i$ tid.

\section{Permisjon på kort varsel}

For min egen del har jeg hatt arbeidsgivere som har vært svært fleksible og vist forståelse for dette, slik at jeg har kunnet reise ut på kort varsel. Jeg vet imidlertid fra flere av mine kolleger at dette heller er unntaket enn regelen. å gjøre det enklere å få godkjent medisinsk arbeid i felten. Har man medisinsk erfaring fra konflikt- og katastrofeområder, er det verdifull kunnskap som også kan være nyttig under norske forhold. Skulle ikke dette kunne godkjennes i alle fall som valgfri sideutdanning? Og om man kan dokumentere relevant arbeid innenfor mer spesialiserte områder, burde man ikke også kunne åpne for noe godkjenning utover valgfri del - for eksempel hiv- eller tuberkuloseprosjektfor en indremedisiner, arbeid ved større feltsykehus for anestesileger og kirurger, og oppdrag ved barnesykehus for pediatere?

Jeg har selv vært igjennom en langvarig

\section{«Norge har et moralsk ansvar til også å støtte leger som reiser ut på rent humanitære oppdrag.»}

I et jobbmiljø hvor man må hevde seg for å sikre videre vikariat, og fast stilling er noe man bare drømmer om, kan det føles frustrerende og risikabelt å presse på for å få nødvendig permisjon til slike oppdrag. Når leger reiser ut med Forsvaret, plikter arbeidsgiver å gi permisjon (1). Norge har et moralsk ansvar til også å støtte leger som reiser ut på rent humanitære oppdrag. En slik støtte kan gis ved å tilrettelegge for at leger kan reise ut på kort varsel, for siden å komme tilbake til sin opprinnelige stilling.

I Overenskomst mellom Spekter og Den Norske Lageforening (2002) står følgende i § 8 Særlige bestemmelser: «Leger kan gis permisjon uten lønn for å arbeide $\mathrm{i}$ internasjonale organisasjoner, Forsvarets internasjonale operasjoner og i norske hjelpetiltak i utviklingsland. Leger som er knyttet til hjelpeorganisasjoner kan gis permisjon i inntil 1 mnd med basislønn pr. kalenderår i forbindelse med utrykning til hjelp for nødstillede» (2). Altså burde leger som ønsker å reise ut med en humanitær organisasjon i alle fall kunne få permisjon til et kortvarig nødhjelpsoppdrag. Kanskje kunne man se nærmere på egne stillinger som kan opprettes for, og deles av, leger som ønsker å arbeide i humanitære organisasjoner i tillegg til å jobbe klinisk her hjemme?

\section{Godkjenning til spesialiteten?}

Et annet tiltak for å gjøre det mer attraktivt for norske leger å bidra humanitært, er søknadsprosess for å få godkjent et knapt halvår av mine oppdrag som valgfri sideutdanning. Det ble godkjent, men jeg opplevde underveis at kravet om å dokumentere veiledning gikk igjen. Dette er et kritisk punkt ved feltarbeid, hvor man ofte jobber som eneste lege i prosjektet. Likevel har man ofte et stort og profesjonelt støtteapparat rundt seg. I prosjekter for Leger Uten Grenser er det mulig for legene å diskutere faglige spørsmål med en medisinsk koordinator, basert i landets hovedstad. I tillegg kan man ha tett kommunikasjon med såkalte medisinske referansepersoner ved hovedkvarterene i Europa. Dette er spesialister innenfor ulike fagområder. Deres oppgave er å støtte fagpersonellet ute i felten, utarbeide retningslinjer med mer.

I tillegg til å oppfordre arbeidsgivere til å være liberale og fleksible i forhold til å gi permisjoner til humanitært feltarbeid, bør det utarbeides klare retningslinjer for godkjenning av valgfri tjeneste til spesialistutdanningen. Man bør også vurdere muligheten for godkjenning av slikt arbeid som spesialiseringsrelevant tjeneste. Forslagsvis kunne man ha godkjent oppdrag inntil seks måneder som valgfri sideutdanning, samt inntil seks måneder som fagspesifikk tjeneste..

Så lenge kravene til prosedyrer, kurs og gruppe 1-tjeneste oppfylles, er det vanskelig å se hva som er i veien for å godkjenne medisinsk arbeid i felten som en del av spesialiseringen. Dette burde være mulig uten å måtte gjennom en tidkrevende og slitsom papirmølle.

\section{Karianne Flaatten \\ karianne@gmx.de \\ Anestesiavdelingen \\ Oslo universitetssykehus, Ullevål \\ 0424 Oslo}

Oppgitte interessekonflikter: Forfatter er styremedlem og visepresident i Leger Uten Grenser Norge.

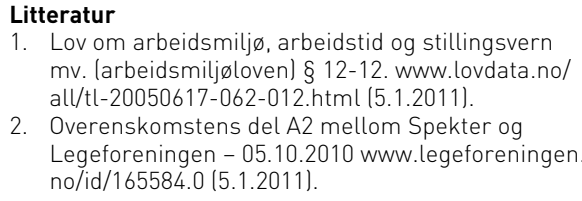
mv. (arbeidsmiljøloven) § 12-12. www.lovdata.no/ all/tl-20050617-062-012.html (5.1.2011).

2. Overenskomstens del A2 mellom Spekter og Legeforeningen - 05.10.2010 www.legeforeningen. no/id/165584.0 (5.1.2011).

Mottatt 16.9. 2010, første revisjon innsendt 1.11. 2010, godkjent 23.12. 2010. Medisinsk redaktør Mette Sagsveen. 